International Journal of Linguistics, Literature and Culture
Available online at https://sloap.org/journals/index.php/ijllc/
Vol. 7, No. 3, May 2021, pages: 158-162
ISSN: 2455-8028
https://doi.org/10.21744/ijllc.v7n3.1519

\title{
Roots of Friendship: Uzbek Literature and Literary Criticism in German Literature during 1960-1970 Years
}

Shukhratkhon Imyaminova a Sadirjan Yakubov ${ }^{b}$

Article history:

Submitted: 27 February 2021

Revised: 9 March 2021

Accepted: 18 April 2021

\section{Keywords:}

international literary relations;

literary contacts;

literary research;

mutual enrichment of literatures;

realistic prose;

religious and mystical literature;

sincere sympathy;

\section{Corresponding author:}

Imyaminova, S.

Department of German Philology, Faculty of Foreign Philology, National University of Uzbekistan named after

Mirzo Ulugbek, Tashkent, Uzbekistan

Email address: sadirjan.yakubov1@gmail.com

\begin{abstract}
Formation and development of literary and cultural contacts, contributed to the domestic and international situation, growing interest in national literatures; acquaintance of the German reader with the life and work of outstanding Uzbek writers and poets, evidence of the sincere sympathy of German scientists, strengthening of international literary relations, assessment of international recognition; Khamza is a talented and multifaceted personality, a well-reasoned assessment of the creativity of Uzbek writers; oppression of the poorest strata of the population, literary theoretical work, fundamental work of German scientists; significant stage, unbiased presentation, horizons of coexistence and development of literatures in the world literary space.
\end{abstract}

International journal of linguistics, literature and culture (C) 2021. This is an open access article under the CC BY-NC-ND license (https://creativecommons.org/licenses/by-nc-nd/4.0/).

a Department of German Philology, Faculty of Foreign Philology, National University of Uzbekistan named after Mirzo Ulugbek, Tashkent, Uzbekistan

b National University of Uzbekistan named after Mirzo Ulugbek, Tashkent, Uzbekistan 


\section{Introduction}

In the $60 \mathrm{~s}-70 \mathrm{~s}$ of the twentieth century in Germany, much attention was paid to the formation and development of cultural and literary contacts, which was largely facilitated by the domestic and international situation. There is a growing interest in national literatures that make up the literary phenomenon "Soviet literature," in particular, in Uzbek literature.

In 1965 in Leipzig the "Lexicon of Literatures of the Nations of the World" was published, in which a number of articles about Uzbek writers were published. They introduced the German reader to the life and work of outstanding Uzbek writers and poets: Alisher Navoi, Hamza Hakimzade Niyazi, Gafur Gulyam, Aibek, and Abdulla Kahhar.

\section{Findings and Results}

The Uzbek-German Dictionary was published, prepared by Doris Schultz, testifying to the sincere sympathy of the German scientist for the Uzbek people, their literature and language. A great contribution to the development of Uzbek-German literary relations was the book "Foreign Writers", published in 1971 in Leipzig. This work introduced the German reader to the work of a number of prominent Uzbek writers (Chu, 1999; Rosengren, 1987).

The book "Die Literaturen der Völker der Sowjetunuon" ("Literature of the peoples of the Soviet Union") was very significant for strengthening the international literary relations of Uzbekistan. In it, an attempt was made to systematically describe the history of the development of Uzbek literature, to identify its origins. Uzbek literature, as noted by the German literary critic G. Dudek, is one of the oldest literatures that have gone through a difficult and long path of development (Die Literaturen, 1967). "The conduct of Islam, as well as the Arabic language", writes G. Dudek, "led to the emergence of religious and mystical literature, which remained predominant until the XIV century" (Die Literature, 1967). G. Dudek highly appreciates the work of Alisher Navoi: "Navoi elevated the Old Uzbek language, with his four volumes of Lyrics and six large poems he gave impetus to the development of Uzbek and other literatures in Central Asia. Navoi's creativity is an achievement of world literature" (Die Literaturen, 1967).

This assessment confirms the international recognition of the outstanding role of the great poet in the development of Uzbek literature. The work notes the cultural and historical significance of the works of the XV-XVI centuries, describing the military campaigns of the Uzbek khans, in particular, the work of Babur (1483-1530), Mashrab (1657-1711), Mukimi (1851-1903), Furkat (1851- 1909), Zavki (1853-1921).

A significant place in the German research is given to the work of the prominent Uzbek writer Hamza Khakimzade Niyazi. It is rightly noted that Uzbek literature is developing in the mainstream of multinational Soviet literature, reflecting the social situation of the time by means of a generally accepted literary trend and at the same time preserving national identity, the originality of the form of displaying the world (Oatley, 1995).

Along with poetry, which has long been developing in the East for many centuries, realistic prose, drama, and Uzbek literary criticism itself have appeared in Uzbek literature. The founder of Uzbek drama, the father of the Uzbek Theater, who had a great influence on the development of literature in Uzbekistan and other republics of Central Asia, was Khamza Khakim-zade Niyazi (Die Literaturen, 1967).

German literary critic G. Dudek provides information about the life and literary analysis of the works of G. Gulyam, H. Alimjan, Aibek, A. Kahhar, K. Yashen, Uigun and Gairati. This literary study, carried out at a high scientific level, contributed to the inclusion of Uzbek literature in a complex system of international literary contacts, identification of Uzbek literature in the world cultural space. In 1975, two more fundamental literary works were published in Germany: "Handbuch der SowjetLiteratur (1917-1972)" and "Multinationale - Sowjetliteratur Kulturrevolution - Menschenbild (1917-1972)".

In the book "Handbuch der Sowjet Literatur (1917-1972)", German literary critics describe in detail the Uzbek literature of the pre-revolutionary and post-revolutionary periods, provide extensive information about Uzbek writers of the new time, paying considerable attention, again, to the work of the Uzbek poet and playwright Hamza Hakim, who spoke Niyazi, who spoke at that time an innovator, the founder of the Uzbek Soviet literature.

A talented and multifaceted personality - a poet, playwright, teacher, composer, publicist and theater director Khamza, as noted in the monograph, is a bright page in the history of the development of Uzbek literature and culture. "The development of non-Russian drama took place within the framework and in accordance with the level of development of individual nations. Khamza created in Uzbekistan with his play "Bai and the laborer" already during the civil war, the Uzbek drama of socialist realism" (Die Literaturen, 1967).

Imyaminova, S., \& Yakubov, S. (2021). Roots of friendship: Uzbek literature and literary criticism in German literature during 1960-1970 years. International Journal of Linguistics, Literature and Culture, 7(3), $158-162$. 
Khamza's works are associated with the fate of a simple, disadvantaged people, imbued with a spirit of sympathy and compassion for him; paint a convincing picture of social injustice, oppression of the poorest strata of the population (De Nooy, 1999; Van Rees, 1983).

The work provides a reasoned assessment of the creativity of such Uzbek writers as G. Gulyam and Aibek, A. Kadiri and A. Kahkhar, K. Yashen and Sh. Rashidov, Zulfiya and A. Mukhtar. Literary critic N. Gelfant writes about the work of the writer Sharaf Rashidov: "The literary-theoretical works of Sh. Rashidov are of great importance for the development of Uzbek literature" (Die Literaturen, 1967). Thus, the "Directory of Soviet Literature (19171972)", published at the Leipzig Bibliographic Institute, is another step towards deepening and expanding the international literary ties of Uzbek literature.

In 1975, the book "Multinationale - Sowjet literatur - Kulturrevolution - Menschenbild (1917-1972)" "Multinational Soviet Literature. Cultural Revolution. The Image of a Man (1917-1972)", written by scientists from the Institute of Literary History of the Academy of Sciences with the direct assistance of the Institute of World Literature named after A.M. Gorky. This fundamental work of German scholars is yet another convincing evidence of the growing prestige of multinational Soviet literature, in particular, Uzbek literature in Germany.

The book convincingly defines the significance of Soviet literature as a multinational phenomenon that brought together various national literatures, productively interacting and mutually enriching (Multinationale Sowietliteratur, 1975). In the work of German scientists, the chronological stages of the development of multinational literature from 1917 to the 70s of the XX century are indicated and characterized.

Much attention in the study is paid to the development of literature. The growth of literacy of the population, the formation of highly developed republics on the territory of Central Asia, the intensive development of culture and science led to the development of distinctive national literatures, rooted in the national traditions of peoples and, at the same time, enriched by the achievements of other national cultures and literatures. Much attention in the study is paid to determining the meaning and role of creativity of the founder of Uzbek literature, Alisher Navoi. Evaluating the songs of Navoi, in the chapter "Diversity and richness of multinational literature", German literary critics note that "Laudatory song about beauty" by A. Navoi has a great positive significance in the formation of "internationalist principles" of today's literature (60s - 70s - S.Ya.) (Multinationale Sowietliteratur, 1975).

Discussing the works of A. Mukhtar, Sh. Rashidov, A. Kahhar, German researchers note that these writers were able to reflect the face of the nation (Multinationale Sowietliteratur, 1975). This fundamental work of German literary scholars contributed to the successful, fruitful solution of many problems in the field of literary cooperation.

As a result of many years of literary contacts between the two countries, the field of literary criticism is being born, exploring the issues of interaction and mutual influence of national literatures, and an important role in this process was played by the works of German literary critics from the publishing house of the Berlin Academy of Sciences ("Aufbau Verlag"). In 1975, a German translation of the monograph by L. Timofeev and G. Lomidze "Literature of the Socialist Society. On the issue of the emergence of multinational Soviet literature (1917-1941)".

"L.Timofeew, G.Lomidse "Literatur einer sozialistischen Gnueinschaft. Zur Herausbildung und Entwichklung der multinationalen Sowjetliteratur (1917-1941)". The book was published in the series "Literature and Society" (Academy of Sciences, Berlin). Another significant stage in the study of the literary works of Uzbek writers in Germany was the book by the prominent German journalist Richard Christ, containing extensive interesting information about the Uzbek people, the sights of the country, "In 100 Days around Half of the Earth", published in 1976 by the publishing house "Aufbau Verlag" (Berlin). The book by Richard Christ allowed the German reader to visit a distant country, to form an unbiased idea of it. The book is of great educational value. No less significant and interesting book about the Uzbek land, its people, traditions was the book by Egon Erwin "Reports from five continents", published in 1976 in Leipzig (Kisch, 1976).

\section{Conclusion}

Research carried out by German scientists, writers, literary scholars, journalists in German publishing houses has intensified the processes of mutual enrichment of literatures, rapprochement of peoples, strengthening of the closest cultural contacts, opening new horizons for the coexistence and development of literatures in the world literary space.

Conflict of interest statement

The authors declared that they have no competing interest. 
Statement of authorship

The authors have a responsibility for the conception and design of the study. The authors have approved the final article.

Acknowledgments

We are grateful to two anonymous reviewers for their valuable comments on the earlier version of this paper.

Imyaminova, S., \& Yakubov, S. (2021). Roots of friendship: Uzbek literature and literary criticism in German literature during 1960-1970 years. International Journal of Linguistics, Literature and Culture, 7(3), $158-162$. https://doi.org/10.21744/ijllc.v7n3.1519 


\section{References}

Chu, C. M. (1999). Literary critics at work and their information needs: A research-phases model. Library \& information science research, 21(2), 247-273. https://doi.org/10.1016/S0740-8188(99)00002-X

De Nooy, W. (1999). A literary playground: Literary criticism and balance theory. Poetics, 26(5-6), 385-404. https://doi.org/10.1016/S0304-422X(99)00009-1

Die Literaturen der Völker der Sowietunion. (1967) VEB Biblio-graphisches Institut Leipzig.

Kisch E.E. (1976) Reportagen aus fünf Kontinenten. Verlag Filipp Reclam Jung. Leipzig.

Multinationale Sowietliteratur. (1975) Kulturrevolution. Menschenbild (1917-1972) Aufbau Verlag Berlin und Weimar.

Oatley, K. (1995). A taxonomy of the emotions of literary response and a theory of identification in fictional narrative. Poetics, 23(1-2), 53-74. https://doi.org/10.1016/0304-422X(94)P4296-S

Rosengren, K. E. (1987). Literary criticism: future invented. Poetics, 16(3-4), 295-325. https://doi.org/10.1016/0304422X(87)90009-X

Van Rees, C. J. (1983). How a literacy work becomes a masterpiece: On the threefold selection practised by literary criticism. Poetics, 12(4-5), 397-417. https://doi.org/10.1016/0304-422X(83)90015-3 